\title{
Expression of the calcium-activated potassium channel in upper and lower segment human myometrium during pregnancy and
} parturition

\author{
$\mathrm{Lu} \mathrm{GaO}^{\dagger 1}$, Binghai Cong ${ }^{\dagger 1}$, Lanmei Zhang ${ }^{2}$ and Xin Ni*1
}

Address: ${ }^{1}$ Department of Physiology, Second Military Medical University, Shanghai 200433, PR China and ${ }^{2}$ Department of Gynecology and Obstetric, Navy General Hospital, Beijing 100037, PR China

Email: Lu Gao - roadgao@yahoo.com.cn; Binghai Cong - congbh2003@yahoo.com.cn; Lanmei Zhang - zzllmm1100@163.com; Xin Ni*-nixin@smmu.edu.cn

* Corresponding author †Equal contributors

Published: 5 April 2009

Reproductive Biology and Endocrinology 2009, 7:27 doi:10.1 186/1477-7827-7-27

This article is available from: http://www.rbej.com/content/7/1/27

(c) 2009 Gao et al; licensee BioMed Central Ltd.

This is an Open Access article distributed under the terms of the Creative Commons Attribution License (http://creativecommons.org/licenses/by/2.0), which permits unrestricted use, distribution, and reproduction in any medium, provided the original work is properly cited.
Received: 13 February 2009

Accepted: 5 April 2009

\begin{abstract}
Background: Large conductance calcium-activated potassium channel (BKCa) plays an important role in the control of uterine contractility during pregnancy. The change from uterine quiescence to enhanced contractile activity may be associated with the spatial and temporal expression of $\mathrm{BKCa}$ within myometrium. The objectives of this study were to examine the expression of $\mathrm{BKCa}$ alpha- and beta-subunit in upper segment (US) and lower segment (LS) regions of uterus, and to investigate for the possibly differential expression of these proteins in US and LS myometrium obtained from three functional states: (I) non-pregnant (NP); (2) term pregnant not in labour (TNL) and (3) term pregnant in labour (TL).

Methods: Myometrial biopsies were collected from non-pregnant women at hysterectomy and pregnant women at either elective caesarean section or emergency caesarean section. Protein expression level and cellular localization of BKCa alpha- and beta-subunit in US and LS myometrium were determined by Western blot analysis and immunohistochemistry, respectively.

Results: $\mathrm{BK}_{\mathrm{Ca}_{\mathrm{a}}}$ alpha- and beta-subunit were predominantly localized to myometrial smooth muscle in both US and LS myometrium obtained from non-pregnant and pregnant patients. The level of BKCa alpha-subunit in US but not in LS was significantly higher in NP myometrium than those measured in myometrium obtained during pregnancy. Lower expression of BKCa alpha-subunit in both US and LS was found in TL than in TNL biopsies. Expression of beta-subunit in both US and LS myometrium was significantly reduced in TL group compared with those measured in TNL group. There was no significant difference in BKCa beta-subunit expression in either US or LS between NP and TNL group.
\end{abstract}

Conclusion: Our results suggest that expression of $\mathrm{BKCa}$ alpha- and beta-subunit in pregnant myometrium is reduced during labour, which is consistent with the myometrial activity at the onset of parturition. 


\section{Background}

During most of pregnancy, myometrium activity is characterized by poorly coordinated contractures. In late pregnancy, the uterus undergoes preparedness for the stimuli that lead to contractility and labour $[1,2]$. The mechanisms that initiate labour in women, particularly the molecular processes that convert the myometrium form a state of relative quiescence to the activated and contractile state, are not well understood. An understanding of these processes, at the molecular and cellular level, is essential to developing novel therapeutic strategies for management of associated clinical problems such as preterm labour that accounts for $85 \%$ of all perinatal complications and death.

It has been known that uterine myometrial contractility at term is triggered by a number of physiological signals, which orchestrate changes in uterine excitability via ionchannel modulation $[3,4]$. Potassium channels are central to regulation of cell membrane potential and contractility of smooth muscle $[4,5]$. Among the diverse families of $\mathrm{K}^{+}$ channels, the large conductance calcium-activated potassium channel $\left(\mathrm{BK}_{\mathrm{Ca}}\right)$ is the predominant $\mathrm{K}^{+}$-channel type expressed in human myometrium [6,7]. This channel is activated by membrane depolarization and also by an increase in the intracellular calcium concentration, thereby playing a pivotal role in the modulation of uterine contractility and myometrial calcium homeostasis $[3,4,8$ 10]. Electrophysiological studies have demonstrated changes in $\mathrm{BK}_{\mathrm{Ca}}$ activity during pregnancy. It was reported by Wang et al. [11] that the contribution of $\mathrm{BK}_{\mathrm{Ca}}$ channels to the total outward $\mathrm{K}^{+}$currents was reduced by about $10 \%$ in pregnant myocyte near term compared with nonpregnant myocyte. Khan and colleagues had shown that the sensitivity of $\mathrm{Ca}^{2+}$ and voltage of this channel in human pregnant myometrium was lost at the time of labor [7]. A number of studies suggested altered $\mathrm{BK}_{\mathrm{Ca}}$ expression in myometrium during pregnancy and parturition. Song et al. [12] worked on rat and found that $\mathrm{BK}_{\mathrm{Ca}}$ is decreased by $60 \%$ in the myometrium of pregnant rats at the end of pregnancy. Benkusky and co-workers [13] reported that $\mathrm{BK}_{\mathrm{Ca}}$ in mouse myometrium is increased during pregnancy and diminished in post-partum. Studies by Khan's group demonstrated $\mathrm{BK}_{\mathrm{Ca}}$ expression in lower segment of human term myometrium and found it is decreased in labour onset [14,15].

It has been implicated that there is a functional regionalization in the myometrium during pregnancy and labour. The upper segment (US) region of the uterus expands to accommodate the growing fetus and then at labour contract to cause expulsion of the fetus, while the lower segment (LS) may maintain a relative quiescence to allow passage of the fetus [16]. Current data about $\mathrm{BK}_{\mathrm{Ca}}$ expression in human myometrium during pregnancy are restricted to the LS $[14,15,17]$. There is no information concerning the expression of $\mathrm{BK}_{\mathrm{Ca}}$ in the different region of uterus during pregnancy and labour that would support its role in the regulation of uterus contractions.

The objectives of the present study were to determine the regional distribution of the $\mathrm{BK}_{\mathrm{Ca}}$ channel in human nonpregnant and term myometrium before and during parturition. Protein levels of $\mathrm{BK}_{\mathrm{Ca}}$ channel were also examined by Western blotting to establish whether the expression of these proteins is changed in pregnancy and labour.

\section{Methods \\ Tissue Collection}

Paired upper and lower uterine segmental myometrial tissues from pregnant and non-pregnant women were collected in Navy General Hospital, the teaching hospital of Second Military Medical University, Beijing, China. Approval of this study was granted by human ethic committee of Navy General Hospital as well as human ethic committee of Second Military Medical University. Written informed consent was obtained from each participant.

Non-pregnant myometrium tissues were obtained from premenopausal, normal, cycling women (mean age $41 \pm$ $4.3 \mathrm{yr}, \mathrm{n}=8$ ) undergoing hysterectomy for fibroids. Pregnant myometrial biopsies were collected at cesarean section form the following groups of pregnant women (37-42 wk): term no labour (mean age, $25 \pm 2.2 \mathrm{yr}$, mean gestational age, $39 \pm 1.7$ weeks, $\mathrm{n}=10$ ) and term labour (mean age 26 $\pm 2.3 \mathrm{yr}$, mean gestational age, $39 \pm 1.6$ weeks $\mathrm{n}=10)$. Labour was defined as regular contractions ( $<5 \mathrm{~min}$ apart) plus membrane rupture and cervical dilation $(>3 \mathrm{~cm})$ with no augmentation (oxytocin or PG administration). Indications for cesarean section included breech presentation, placenta previa, previous cesarean section, cephalopelvic disproportion, failure of labour to progress, fetal distress, or maternal request. None of the women included in this study had evidence of underlying disease (e.g. hypertension, diabetes, preeclampsia, intrauterine growth restriction, etc.). LS uterine samples were collected from the upper margin of the LS uterine incision, while US uterine samples were taken from just below fundus. Because there is no LS in non-pregnant uterus, tissues taken from the isthmus of non-pregnant uterus were treated to be equivalent to the LS of pregnant uterus. All non-pregnant tissues were taken from the normal part of uterus without fibrosis contamination. Collected samples were placed in phosphatebuffered saline on ice and transported to the laboratory. For Western blot analysis, tissues were then frozen immediately in liquid nitrogen and stored at $-80^{\circ} \mathrm{C}$. For immunohistochemical analysis, the biopsies were placed in $10 \%$ phosphate buffered formalin.

\section{Immunohistochemistry}

Immunohistochemical investigations were performed with the Histostain-SP kit (Zymed, San Franscisco, CA), 
which uses a biotinylated second antibody, a horseradish peroxidase-streptavidin conjugate, and a substrate-chormogen mixture to demonstrate antigen in the tissue. The specific antibodies, anti- $\alpha_{1184-1200}$ and anti- $\beta_{1-191}$, were purchased from Alomone Labs (Alomone Labs Ltd. Jerusalem, Israel) and Santa Cruz Biotechnology (Santa Cruz Biotechnology, Inc. Santa Cruz, CA), respectively. The anti- $\alpha_{1184-1200}$ antibody recognizes amino acid residues $1184-1200$ at the $C$ terminus of the $\alpha$-subunit. Anti- $\beta_{1-191}$ antibody recognizes full length residues of $\beta$-subunit. Paraffin sections $(5 \mu \mathrm{m})$ were cut, rehydrated and microwaved in citric acid buffer to retrieve antigens. After inhibition of endogenous peroxidases with $3 \% \mathrm{H}_{2} \mathrm{O}_{2}$, unspecific antibody binding was blocked with $10 \%$ rabbit serum for $30 \mathrm{~min}$. The tissue sections were then incubated with specific antibody against $\mathrm{BK}_{\mathrm{Ca}} \alpha$ - or $\beta$-subunit (1:500). The bound antibodies were detected with the biotin-streptavidin-peroxidase system (UltraSensitive-SPkit, MaiXin Biotechnology, Fuzhou, China) using diaminobenzidine (Sigma) as chromogen. Counterstaining was performed with hemalum. Negative controls were performed by substituting primary antibody with a normal serum in same dilution. To confirm the specificity of primary antibody, preabsorption of the primary antibody with a ten-fold excess of the blocking peptides was performed.

\section{Western blot analysis}

Approximately $70 \mathrm{mg}$ of human myometrial tissue was homogenized in ice-cold lysis buffer consisting of $60 \mathrm{mM}$ Tris- $\mathrm{HCl}, 2 \%$ sodium dodecyl sulfate (SDS), 10\% sucrose, $2 \mathrm{mM}$ phenylmethylsulfonyl fluoride (Merck, Darmstadt, Germany), 1 mM sodium orthovanadate (Sigma-Aldrich), $10 \mu \mathrm{g} / \mathrm{ml}$ aprotinin (Bayer, Leverkusen, Germany). Lysates were then quickly ultrasonicated in ice bath, boiled 5 min at $95 \mathrm{C}$, and stored at $-80^{\circ} \mathrm{C}$ until used. Protein concentrations were measured using a modified Bradford assay and samples were diluted in sample buffer $(250$ $\mathrm{mM}$ Tris-HCl (pH 6.8), containing 4\% SDS, $10 \%$ glycerol, $2 \% \beta$-mercaptoethanol, and $0.002 \%$ bromophenol blue) and boiled for a further $5 \mathrm{~min}$. Samples were separated on an SDS-8\% polyacrylamide gel, and the proteins were electrophoretically transferred to a nitrocellulose filter at $300 \mathrm{~mA}$ for $1.5 \mathrm{~h}$ in a transfer buffer containing $20 \mathrm{mM}$ Tris, $150 \mathrm{mM}$ glycine, and $20 \%$ methanol. The filter was then blocked in TBS containing 0.1\% Tween-20(TBST) and $5 \%$ dried milk powder (wt/vol) for $2 \mathrm{~h}$ at room temperature. After three washes with TBST, the nitrocellulose filters were incubated with primary antibody for $\mathrm{BK}_{\mathrm{Ca}} \alpha$ or $\beta$-subunit $(1: 500)$ at $4{ }^{\circ} \mathrm{C}$ overnight. After another three washes with TBST, the filters were incubated with a secondary horseradish peroxidase-conjugated IgG (1:1000) for $1 \mathrm{~h}$ at room temperature and further washed for 30 min with TBST. Immunoreactive proteins were visualized using the enhanced chemiluminescence Western blotting detection system (Santa Cruz). The light-emitting bands were detected with X-ray film. The resulting band intensities were quantitated using an image scanning densitometer (Furi Technology, Shanghai, China). To control sampling errors, the ratio of band intensities to $\beta$-actin was obtained to quantify the relative protein expression level.

\section{Statistical analysis}

Protein levels of $\mathrm{BK}_{\mathrm{Ca \alpha}}-$ and $\beta$-subunit were determined by densitometric analysis (Furi Technology, Shanghai, China). Peak count values were expressed as densitometric units. The data are presented as mean \pm SEM. All data were tested for homogeneity of variance by Bartlett's test. The results indicated that the data were normally distributed. Individual comparisons were made by Student's ttest for paired data. One-way ANOVA with Student-Newman-Keuls was used for multiple comparisons. $P$-value of $<0.05$ was considered to be significant.

\section{Results \\ Expression of the $\alpha$ - and $\beta$-subunit of $B K_{\mathrm{Ca}_{a}}$ in non-pregnant and pregnant myometrium}

Positive immunoreactivity for $\mathrm{BK}_{\mathrm{Ca}} \alpha$-and $\beta$-subunit was identified in both US and LS myometrium from non-pregnant and pregnant women. Immunohistochemistry revealed that $\mathrm{BK}_{\mathrm{Ca}} \alpha$ - and $\beta$-subunit were predominantly localized to smooth muscle cells of myometrium. Smooth muscle cells lining blood vessel were also positively stained for these proteins (Fig 1 and 2). Immunoreactivity was abolished when the antibody was preabsorbed with excess peptide, thereby confirming the specificity of antibody (Fig $1 \mathrm{E}$ and $1 \mathrm{~F}$ ).

Western blot analysis, using $\alpha$ - and $\beta$-subunit-specific antibodies, detected bands of 110 and $35 \mathrm{kDa}$, respectively (Fig 3A). To given an overall expression profile in the US and LS, the expression values from all the pregnant patients were combined. When the overall expression level of each protein was compared in the pregnant upper and lower myometrium samples, there were no significant differences in either $\alpha$ - or $\beta$-subunit levels between US and LS myometrium (Fig 3B and 3C).

\section{Pregnancy and labour associated changes in the expression of $\mathrm{BK}_{\mathrm{Ca}} \alpha$-subunit}

Within US myometrium, the expression level of $\alpha$-subunit protein was significantly down-regulated in pregnant samples compared to that of the non-pregnant samples (NP versus all other groups, $P<0.01$, Fig $4 \mathrm{~A}$ ). It was further decreased in TL samples compared to TNL samples $(P$ $<0.05$, Fig. 4A).

Within LS, however, no significant differences in the expression of $\alpha$-subunit protein were observed among NP 

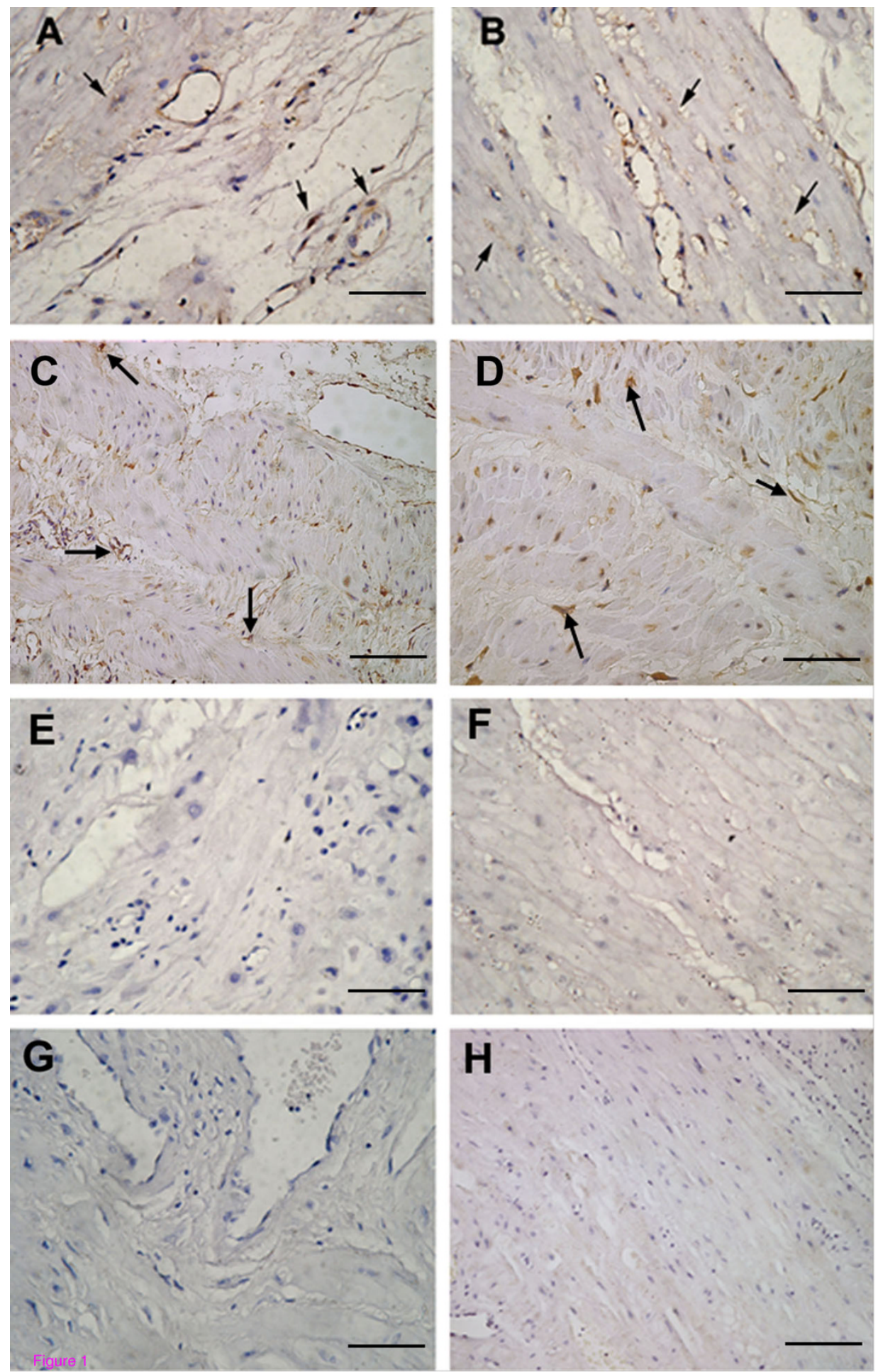

\section{Figure I}

Immunolocalization of $\mathbf{B K}_{\mathbf{C a}_{\mathbf{a}}}$ channel $\alpha$ - and $\beta$-subunit in non-pregnant myometrium. Positive staining for the $\alpha$ subunit of $\mathrm{BK}_{\mathrm{Ca}}$ (arrow) in (A) US myometrium and (B) LS myometrium. Positive staining for the $\beta$-subunit (arrow) in (C) US myometrium and (D) LS myometrium. (E-H) Negative controls. The primary antibody was substituted with (E) normal rabbit serum or (G) PBS. Sections were stained with $(F) \alpha$-subunit preabsorption antibody or $(H) \beta$-subunit preabsorption antibody. Original magnification $\times 400$. 


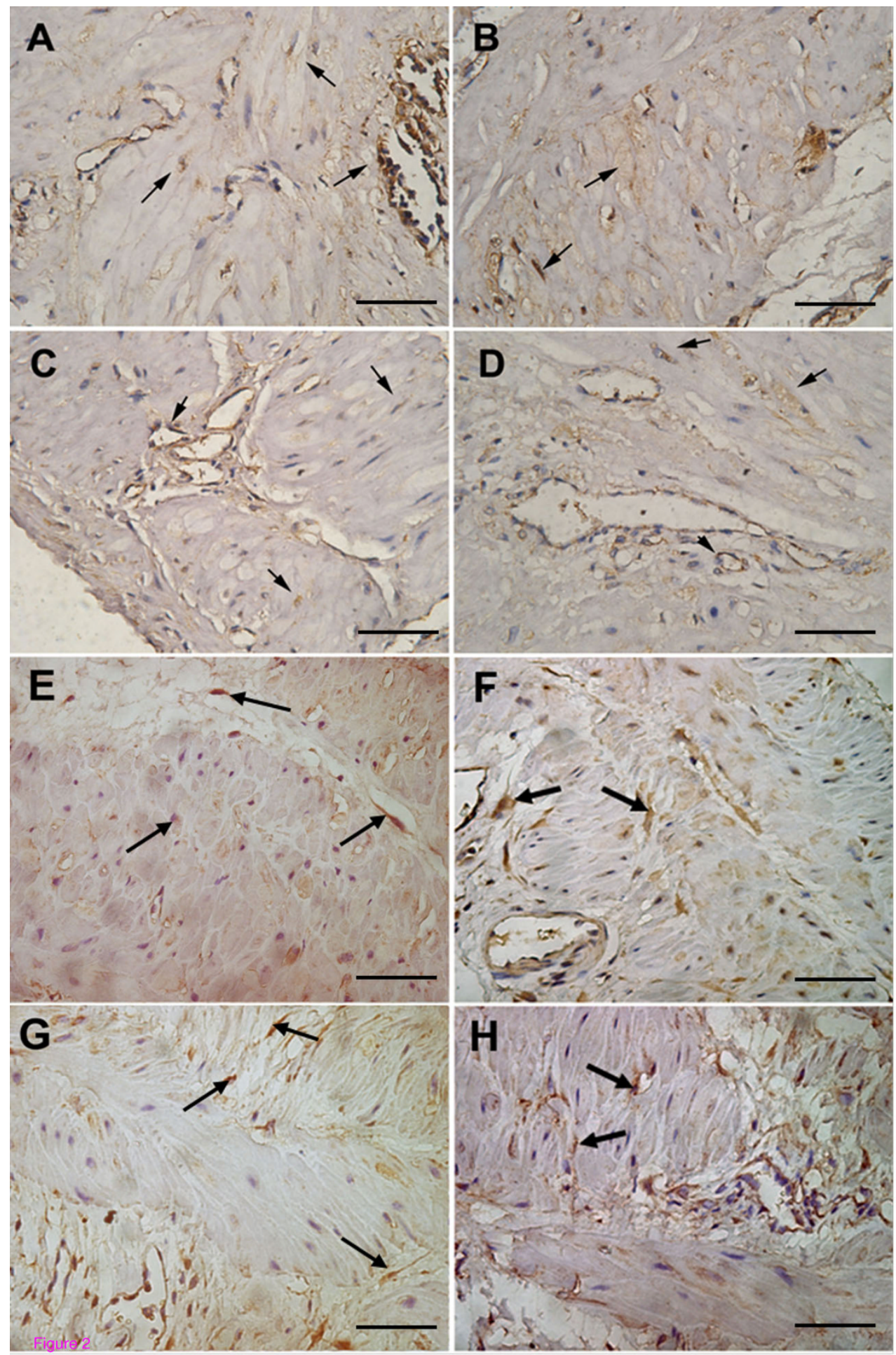

Figure 2

Immunolocalization of $\mathrm{BK}_{\mathrm{Ca}}$ channel $\alpha$ - and $\beta$-subunit in myometrium from pregnant women at term in labour or not in labour. A-D shows representative sections for positive staining for $\alpha$-subunit in (A) US myometrium not in labour, (B) LS myometrium not in labour, (C) US myometrium in labour and (D) LS myometrium in labour. E-H shows representative sections for positive staining for $\beta$-subunit in (E) US myometrium not in labour, (F) LS myometrium not in labour, (G) US myometrium in labour and $(\mathrm{H})$ LS myometrium in labour. Arrow: positive staining. Original magnification $\times 400$. 


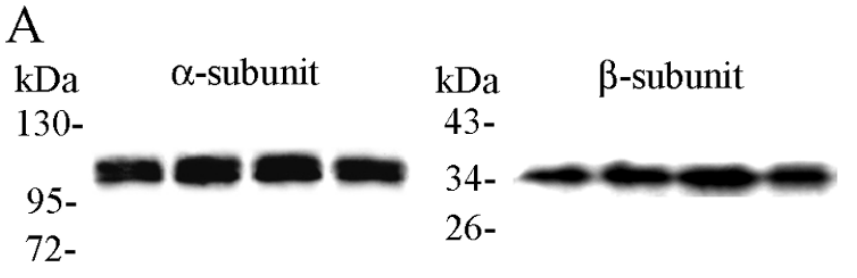

B

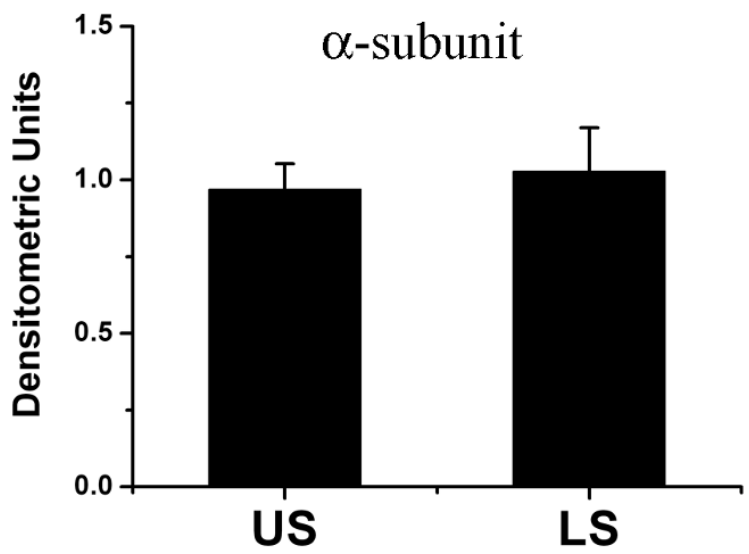

$\mathrm{C}$

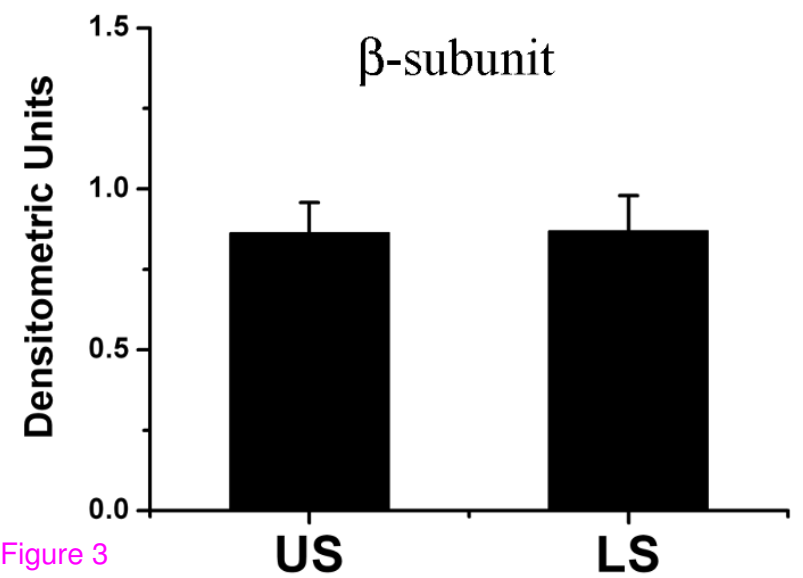

Figure 3

Western blot analysis of $B K_{C_{a}} \alpha-$ and $\beta$-subunit in pregnant US and LS myometrium. (A) Representative immunoblots showing the expression of the $110 \mathrm{kDa} \alpha$-subunit and the $35 \mathrm{kDa} \beta$-subunit in human myometrium. (B, C) The expression values of $\alpha$ - and $\beta$-subunit from all the pregnant patients was combined to given an overall expression profile in the US and LS. Data were expressed as mean \pm SEM.

and TNL groups. This protein was significantly down-regulated in TL samples compared to that in TNL samples $(P$ $<0.01$, Fig. 4B).

\section{Pregnancy and labour associated changes in the} expression of $B K_{C a} \beta$-subunit

Within US, expression of $\beta$-subunit protein was significantly decreased in TL group (TL versus TNL, $P<0.05$, TL versus NP, $P<0.01$, Fig. 5A). Within LS, $\beta$-subunit protein level was significantly lower in TL group than that in TNL or NP group $(P<0.01$, Fig. 5B). No marked changes in either US or LS were observed in pregnancy (NP versus TNL).

\section{Discussion}

The present study demonstrated, for the first time, the expression of $\alpha$ - and $\beta$-subunit of $\mathrm{BK}_{\mathrm{Ca}}$ in paired US and LS tissues from non-pregnant and pregnant women. $\mathrm{BK}_{\mathrm{Ca}}$ $\alpha$ - and $\beta$-subunit were mainly localized to myometrial smooth muscle cells in the US and LS. The levels of these proteins were significantly down-regulated in both US and LS at the time of labour.

Studies by Khan's group showed that the expression of both $\mathrm{BK}_{\mathrm{Ca}} \alpha$ - and $\beta$-subunit in LS region of uterus was significantly reduced during labour [14,15]. Curley et al. [17] also found decreased mRNA level of the $\alpha$-subunit of $\mathrm{BK}_{\mathrm{Ca}}$ in LS with labour onset. In consistence with the above studies, the present study also showed the labour associated decrease in the expression of $\alpha$ - and $\beta$-subunit proteins within LS myometrium. In addition, we also investigated the localization and expression pattern of $\mathrm{BK}_{\mathrm{Ca}}$ within US during pregnancy and labour. Our data suggest that $\alpha$ - and $\beta$-subunit of $\mathrm{BK}_{\mathrm{Ca}}$ in US region is significantly down-regulated at the onset of labour.

Current data outlining pregnancy associated expression of $\mathrm{BK}_{\mathrm{Ca}}$ protein in LS region of human uterus are not fully consistent. Zhou et al. [18] reported that $\mathrm{BK}_{\mathrm{Ca}} \alpha$-subunit protein in LS region remained virtually unchanged in pregnant human myometrium, compared to non-pregnant myometrium, whereas $\beta$-subunit protein was lower in pregnant tissues than in non-pregnant tissues. Matharoo-Ball et al. [15] showed that $\mathrm{BK}_{\mathrm{Ca}} \alpha$-subunit was increased whereas $\beta$-subunit was decreased during pregnancy compared to the non-pregnant state. However, no studies to date appear to have examined $\mathrm{BK}_{\mathrm{Ca}}$ in US myometrium of pregnant and non-pregnant women. In the present study, within LS region, no significant pregnancy associated changes in the expression of either $\alpha$ - or $\beta$-subunit were observed. Within US, $\alpha$-subunit expression was decreased in pregnancy. In animal studies, a decrease in $\mathrm{BK}_{\mathrm{Ca}} \alpha$-subunit protein levels close to or at term in rat myometrium [12] and an increase in the expression of $\mathrm{BK}_{\mathrm{Ca}} \alpha$ and $\beta 1$ subunit throughout gestation in mouse myometrium [19] have been reported.

A lot of studies indicate differential expression of a variety of proteins including connexin-43, G proteins and prostaglandin receptors between US and LS myometrium with labour [20-24], which support the idea that increased contractility of the fundus compared to the lower segment during labour. However, similar expression levels of a few contraction-associated proteins (CAPs) in US and LS with 


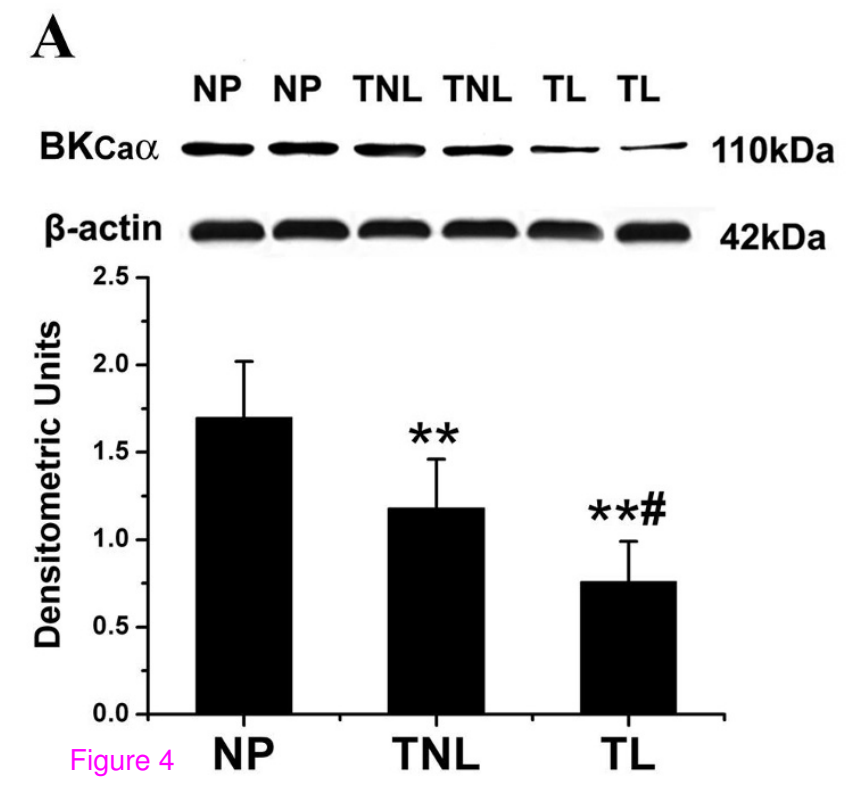

B

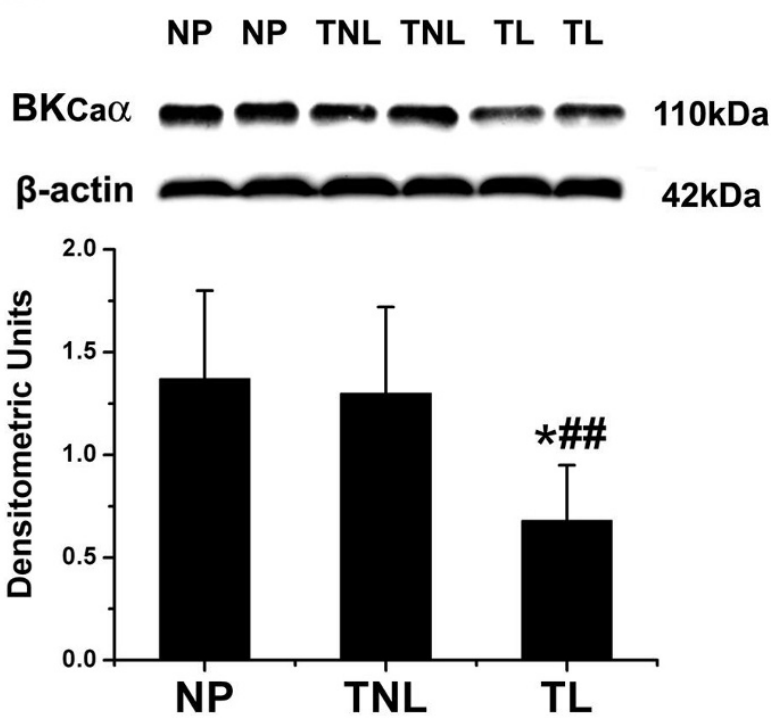

Figure 4

Semiquantitation of Western blot signals of $\mathbf{B K}_{\mathrm{Ca}_{\mathbf{a}}} \alpha$-subunit in US and LS myometrium. Myometrial tissues were obtained from non-pregnant women $(n=8)$ and pregnant women at term before the onset of labour $(n=10)$ or during active labour $(\mathrm{n}=10)$. (A) Levels of $\alpha$-subunit in US samples. (B) $\alpha$-subunit expression in LS samples. Representative protein bands were presented on the top of the histogram. Data were expressed as mean \pm SEM. $* P<0.05$, $* * P<0.01$ with NP; \#P<0.05, $\# \#>0.01$ with TNL.

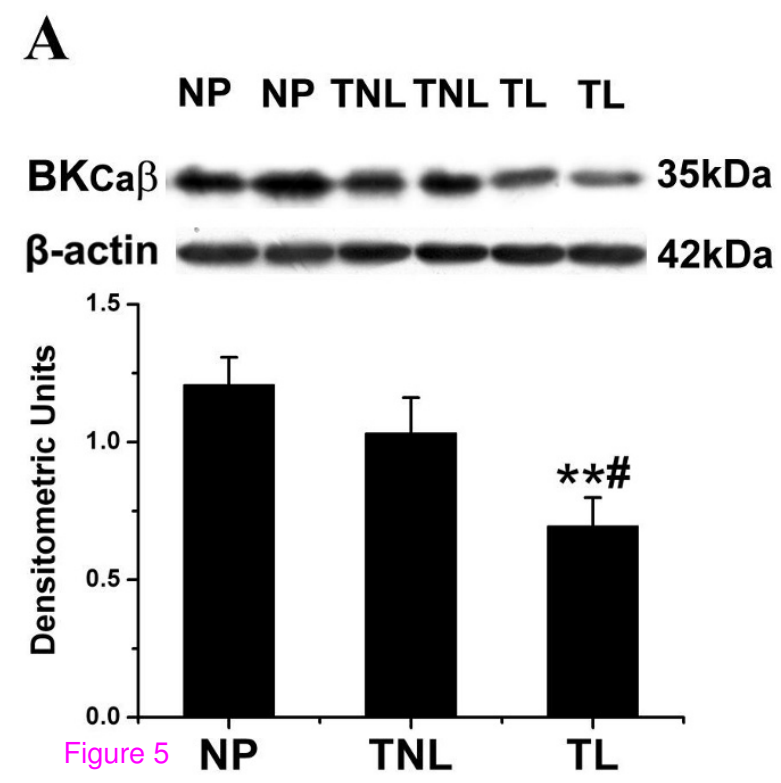

\section{B}

NP NP TNLTNL TL TL
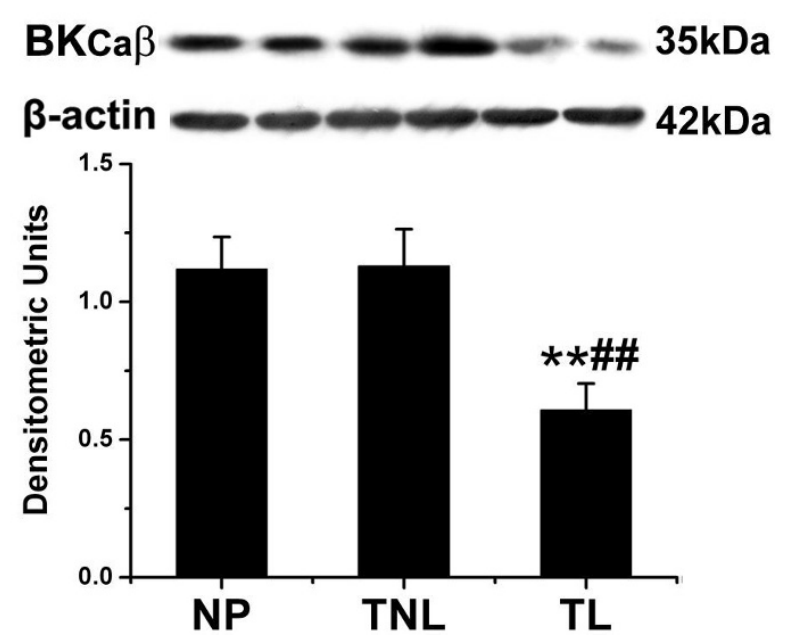

Figure 5

Semiquantitation of Western blot signals of $\mathbf{B K}_{\mathrm{Ca}_{\mathbf{a}}} \beta$-subunit in US and LS myometrium. Myometrial biopsies were obtained from nonpregnant women $(n=8)$ and pregnant women at term not in labour $(n=10)$ or during active labour $(n=10)$ (A) $B K_{C_{a}} \beta$-subunit expression in US, (B) $B_{C_{a}} \beta$-subunit level in LS. Representative protein bands were presented on the top of the histogram. Data were expressed as mean \pm SEM. ${ }^{* * P}<0.01$ with NP; \#P $<0.05$, \#\# $<0.01$ with TNL. 
labour have also been reported [21,25,26]. For instance, Havelock et al. [26] showed that S100A9 mRNA was upregulated in both US and LS during labour. Our results indicate that the similar expression pattern of $\mathrm{BK}_{\mathrm{Ca}}$ in US and LS is occurred with the onset of labour. Together, it suggests that the contractile activity of US or LS region is not likely to be determined by a single specific protein but rather by a combination of all CAPs.

The smooth muscle $\mathrm{BK}_{\mathrm{Ca}}$ channel is formed by tetrameric assembly of an $\alpha$ subunit and an accessory $\beta$-subunit [27]. The $\alpha$-subunit forms the functional $\mathrm{BK}_{\mathrm{Ca}}$ channel $[28,29]$. The presence of the $\beta$-subunit confers $\mathrm{BK}_{\mathrm{Ca}}$ with higher $\mathrm{Ca}^{2+}$ and voltage sensitivity $[10,30]$. Thus, reduced expression of $\mathrm{BK}_{\mathrm{Ca}} \alpha$ - and $\beta$-subunit would permit an increase intracellular $\mathrm{Ca}^{2+}$ levels without permit an increase opposing $\mathrm{K}^{+}$conductance, thereby enhancing contractility of smooth muscle. Because the $\mathrm{BK}_{\mathrm{Ca}}$ channel is particular abundant in uterine myocytes, a reduction of this channel in protein level would translate into a considerable shift toward electrical excitability in the human uterus and likely promote contractile activity.

\section{Conclusion}

Our results indicate that $\mathrm{BK}_{\mathrm{Ca}} \alpha$ - and $\beta$-subunit are predominately localized to myometrial cells in US and LS region of pregnant and non-pregnant human uterus. It has been implicated that, at the time of labour, the uterus differentiates into the highly contractile activity. Because $\mathrm{BK}_{\mathrm{Ca}}$ channel play a pivotal role in the modulation of uterine excitability and contractility, the down-regulation of $\mathrm{BK}_{\mathrm{Ca}}$ channel expression in myometrium following labour may contribute, in part, to the enhanced contractility during parturition.

\section{Competing interests}

The authors declare that they have no competing interests.

\section{Authors' contributions}

LG and BC carried out all experimental work. LZ recruited patients, organized the collection of tissues. $\mathrm{XN}$ conceived of the study, and participated in its design and coordination. All authors read and approved the final manuscript.

\section{Acknowledgements}

The authors wish to thank the nursing and medical staff of the delivery suite, and the patients at Navy General Hospital for their participation. This work is supported by National Natural Science Foundation of China No. 3057596 I and No. 308 I I 20433, and Shanghai Educational Development Foundation No. 2008 CG46.

\section{References}

I. Lye SJ, Freitag CL: Local and systemic control of myometrial contractile activity during labour in the sheep. J Reprod Fertil 1990, 90:483-492.
2. Challis J, Matthews SG, Gibb W, Lye SJ: Endocrine and paracrine regulation of birth at term and preterm. Endocr Rev 2000, 21:I-37.

3. Boyle MB, MacLusky NJ, Naftolin F, Kaczmarek LK: Hormonal regulation of $\mathrm{K}^{+}$-channel messenger RNA in rat myometrium during oestrus cycle and in pregnancy. Nature 1987, 330:373-375.

4. Khan RN, Matharoo-Ball B, Arulkumaran S, Ashford LJ: Potassium channels in the human myometrium. Exp Physiol 200I, 86:255-264.

5. Brayden JE: Potassium channels in vascular smooth muscle. Clin Exp Pharmacol Physiol 1996, 23:1069-1076.

6. Khan RN, Smith SK, Morrison JJ, Ashford ML: Properties of largeconductance $\mathrm{K}+$ channels in human myometrium during pregnancy and labour. Proc Biol Sci 1993, 25 I:9-15.

7. Khan RN, Smith SK, Morrison JJ, Ashford ML: $\mathbf{C a}^{2+}$ dependence and pharmacology of large-conductance $\mathrm{K}^{+}$channels in nonlabor and labor human uterine myocytes. Am J Physiol 1997, 273(5 pt I): $172|-173|$.

8. Anwer K, Oberti C, Perez G], Perez-Reyes N, McDougall JK, Monga M, Sanborn BM, Stefani E, Toro L: Calcium-activated $\mathbf{K}^{+}$channels as modulators of human myometrial contractile activity. Am J Physiol 1993, 265: C976-C985.

9. Tanaka Y, Koike K, Toro L: MaxiK channel roles in blood vessel relaxations induced by endothelium-derived relaxing factors and their molecular mechanisms. J Smooth Muscle Res 2004, 40:125-153

10. Tanaka Y, Koike K, Alioua A, Shigenobu K, Stefani E, Toro L: Beta Isubunit of MaxiK channel in smooth muscle: a key molecule which tunes muscle mechanical activity. J Pharmacol Sci 2004, 94:339-347.

II. Wang SY, Yoshino M, Sui JL, Wakui M, Kao PN, Kao CY: Potassium currents in freshly dissociated uterine myocytes from nonpregnant and late-pregnant rats. J Gen Physiol 1998, I I 2:737-756.

12. Song M, Zhu N, Olcese R, Barila B, Toro L, Stefani E: Hormonal control of protein expression and mRNA levels of the MaxiK channel alpha subunit in myometrium. FEBS Lett 1999, 460:427-432.

13. Benkusky NA, Fergus DJ, Zucchero TM, England SK: Regulation of the $\mathrm{Ca}^{2+}$-sensitive domains of the Maxi-K channel in the mouse myometrium during gestation. I Biol Chem 2000, 275:277|2-277|9.

14. Chanrachakul B, Matharoo-Ball B, Turner A, Robinson G, BroughtonPipkin F, Arulkumaran S, Khan RN: Immunolocalization and protein expression of the alpha subunit of the large-conductance calcium-activated potassium channel in human myometrium. Reproduction 2003, 126:43-48.

15. Matharoo-Ball B, Ashford ML, Arulkumaran S, Khan RN: Down-regulation of the alpha- and beta-subunits of the calcium-activated potassium channel in human myometrium with parturition. Biol Reprod 2003, 68:2135-2141.

16. Pritchard JA, MacDonald PC, Gant NF: The placenta and fetal membranes and maternal adaptation to pregnancy. In Williams' obstetrics 17th edition. Appleton Century Crofts, Stamford, CT; 1985:295-320.

17. Curley M, Morrison JJ, Smith TJ: Analysis of Maxi-K alpha subunit splice variants in human myometrium. Reprod Biol Endocrinol 2004, 2:67-75.

18. Zhou XB, Wang GX, Ruth P, Huneke B, Korth M: BK(Ca) channel activation by membrane-associated cGMP kinase may contribute to uterine quiescence in pregnancy. Am J Physiol Cell Physiol 2000, 279:175I-I759.

19. Benkusky NA, Korovkina VP, Brainard AM, England SK: Myometrial maxi-K channel betal subunit modulation during pregnancy and after I7beta-estradiol stimulation. FEBS Lett 2002, 524:97-I02.

20. Sparey C, Robson SC, Bailey J, Lyall F, Europe-Finner GN: The differential expression of myometrial connexin-43, cyclooxygenase-I and -2, and Gs alpha proteins in the upper and lower segments of the human uterus during pregnancy and labor. J Clin Endocrinol Metab 1999, 84:1705-1710.

21. Bukowski R, Hankins GD, Saade GR, Anderson GD, Thornton S: Labor-associated gene expression in the human uterine fundus, lower segment, and cervix. PLoS Med 2006, 3:el69. 
22. Astle S, Thornton S, Slater DM: Identification and localization of prostaglandin E2 receptors in upper and lower segment human myometrium during pregnancy. Mol Hum Reprod 2005, I I:279-287.

23. Grigsby PL, Sooranna SR, Adu-Amankwa B, Pitzer B, Brockman DE, Johnson MR, Myatt L: Regional expression of prostaglandin E2 and F2alpha receptors in human myometrium, amnion, and choriodecidua with advancing gestation and labor. Biol Reprod 2006, 75:297-305.

24. Otun HA, MacDougall MW, Bailey J, Europe-Finner GN, Robson SC: Spatial and temporal expression of the myometrial mitogenactivated protein kinases $\mathrm{p} 38$ and ERKI/2 in the human uterus during pregnancy and labor. J Soc Gynecol Investig 2005, 12:185-190.

25. Sooranna SR, Grigsby PL, Engineer N, Liang Z, Sun K, Myatt L, Johnson MR: Myometrial prostaglandin E2 synthetic enzyme mRNA expression: spatial and temporal variations with pregnancy and labour. Mol Hum Reprod 2006, I 2:625-63I.

26. Havelock JC, Keller P, Muleba N, Mayhew BA, Casey BM, Rainey WE, Word RA: Human myometrial gene expression before and during parturition. Biol Reprod 2005, 72:707-719.

27. Knaus HG, Garcia-Calvo M, Kaczorowski G], Garcia ML: Subunit composition of the high conductance calcium-activated potassium channel from smooth muscle, a representative of the mSlo and slowpoke family of potassium channels. J Biol Chem 1994, 269(6):392I-3924.

28. Knaus HG, Eberhart A, Glossmann H, Munujos P, Kaczorowski G], Garcia ML: Pharmacology and structure of high conductance calcium-activated potassium channels. Cell Signal 1994, 6:86I-870.

29. Toro L, Wallner M, Meera P, Tanaka Y: Maxi-KCa, a unique member of the voltage-gated K channel superfamily. News Physiol Sci 1998, 13:1 12-117.

30. Meera $\mathrm{P}$, Wallner $M$, Jiang $Z$, Toro $L$ : A calcium switch for the functional coupling between alpha (hslo) and beta subunits (KV, Ca beta) of maxi K channels. FEBS Lett 1996, 382:84-88.

Publish with Bio Med Central and every scientist can read your work free of charge

"BioMed Central will be the most significant development for disseminating the results of biomedical research in our lifetime. "

Sir Paul Nurse, Cancer Research UK

Your research papers will be:

- available free of charge to the entire biomedical community

- peer reviewed and published immediately upon acceptance

- cited in PubMed and archived on PubMed Central

- yours - you keep the copyright

Submit your manuscript here:

http://www.biomedcentral.com/info/publishing_adv.asp
BioMedcentral 